\title{
A Systematic Detection for Brucellosis at Chronic Stage of Infection in Semen of Sheep and Saanen Goats
}

\author{
Esra Buyukcangaz ${ }^{1, a, *}$, Burcu Ustuner²,b, Sevil Erdenlig, ${ }^{3, c}$, Selim Alcay ${ }^{2, d}$, Huban Gocmen ${ }^{4, e}$ \\ M. Berk Toker ${ }^{2, \mathrm{f}}$, Engin Kennerman ${ }^{5, \mathrm{~g}}$, Mihriban Ulgen ${ }^{1, \mathrm{~h}}$ \\ ${ }^{I}$ Department of Microbiology, Faculty of Veterinary Medicine, Bursa Uludă̆ University, 16059 Nilufer/Bursa, Turkey. \\ ${ }^{2}$ Department of Artificial Insemination, Faculty of Veterinary Medicine, Bursa Uludağ University, 16059 Nilufer/Bursa, Turkey. \\ ${ }^{3}$ Department of Microbiology, Faculty of Veterinary Medicine, Harran University, 63200 Eyyübiye/Şanluurfa, Turkey \\ ${ }^{4}$ Department of Microbiology, Faculty of Veterinary Medicine, Near East University, 99138 Nicosia/Northern Cyprus, Mersin -10, Turkey. \\ ${ }^{5}$ Department of Internal Medicine, Faculty of Veterinary, Medicine Bursa Uludag University, 16059 Nillufer/Bursa, Turkey
} *Corresponding author

\begin{tabular}{l|l}
\hline A R T I C L E I N F O & A B S T R A C T \\
\hline Research Article & $\begin{array}{l}\text { The study was conducted in a herd (n: 244) in which goats (n: 206) and sheep (n:38) had a history of brucellosis } \\
\text { in Bursa which is located in Northwestern of Turkey between the years 2012-2014. For the detection of Brucella } \\
\text { spp. and the other zoonotic bacterial agents, semen samples were taken from Saanen goats (n: 35) and rams (n: } \\
\text { 8). Samples were tested by routine diagnostic procedures and PCR. The serum samples of male animals were } \\
\text { also tested for Brucellosis by C-ELISA and I-ELISA. The culture results represented Trueperella pyogenes (n:2), } \\
\text { Pasteurella pneumotopica (n: 5), Esherichia coli (n: 3), Aeromonas salmonicida subs. Salmonicida (1), } \\
\text { Brevundimonas vesicularis } \text { (n: 2) and Mycoplasma bovigenitalium (n: } 1) \text { and Mycoplasma arginini (n: 1) from } \\
\text { semen samples. Rams had no symptoms due to epididymitis or epididymoorchitis in clinical examination, but } \\
\text { two bucks showed orchitis and they were serologically positive for brucellosis. Also, one seronegative buck } \\
\text { showed epididymitis in a flock. There were no statistically significant differences between the serologically } \\
\text { positive and negative animals in an examination of semen samples in terms of their volume, concentration, mass } \\
\text { activity, motility and defectivity rate for acrosome. Although 20 of the serum samples were negative for anti- } \\
\text { Brucella antibody, 23 of them were serologically positive for brucellosis. As a result of this study, Brucellae } \\
\text { were not detected by bacteriologically and molecularly while there were some positive serum samples for } \\
\text { brucellosis. This could be attributed that these samples might have been collected from chronically infected } \\
\text { animals in which animals generally do not shed the organisms. Therefore, it was thought that sampling with } \\
\text { regular intervals might help for the definitive incidence of brucellosis. }\end{array}$ \\
$\begin{array}{l}\text { Keywords: } \\
\text { Goat }\end{array}$ \\
$\begin{array}{l}\text { Ram } \\
\text { Brucellosis }\end{array}$ \\
$\begin{array}{l}\text { Semen } \\
\text { ELISA } \\
\text { PCR }\end{array}$
\end{tabular}
Türk Tarım - Gıda Bilim ve Teknoloji Dergisi 7(10): 1670-1677, 2019

\section{Koyun ve Saanen keçilere ait semenlerden sistematik deteksiyon ile kronik Bruselozisin tanısı}

\begin{tabular}{|c|c|}
\hline M A K A L E B İ L G İ S İ & Ö Z \\
\hline $\begin{array}{l}\text { Anahtar Kelimeler: } \\
\text { Teke } \\
\text { Koç } \\
\text { Brucellosis } \\
\text { Semen } \\
\text { ELISA } \\
\text { PCR }\end{array}$ & $\begin{array}{l}\text { Çalışma, 2012-2014 yılları arasında Türkiye'nin kuzeybatısında yer alan Bursa ilinde brucellosis geçmişli keçi } \\
\text { (n: 206) ve koyunlara (n: 38) ait bir sürüden (n: 244) örneklemeler suretiyle yapıldı. Saanen keçilerinden (n: 35) } \\
\text { ve koçlardan (n: 8) alınan semen örnekleri Brucella spp. ve diğer zoonotik bakteriyel ajanların tespiti amacıyla } \\
\text { çalışıldı. Örnekler, rutin tanısal prosedürler ve PCR ile test edildi. Erkek hayvanlardan alınan serum örnekleri } \\
\text { ayrıca C-ELISA ve I-ELISA ile Bruselloz yönünden test edildi. Kültür sonuçları; Semen örneklerinden } \\
\text { Trueperella pyogenes (n: 2), Pasteurella pneumotopica (n: 5), Esherichia coli (n: 3), Aeromonas salmonicida } \\
\text { sub. Salmonicida (n:1), Brevundimonas vesicularis (n: 2) ve Mycoplasma bovigenitalium (n: 1) ve Mycoplasma } \\
\text { arginini (n: 1) izole edildi. Klinik muayenede ise koçlarda epididimitis veya epididimoorşit kaynaklı semptom } \\
\text { olmamasına karşın serolojik olarak bruselloz pozitif olan iki adet koç orşitis idi. Ayrıa bir seronegatif koç } \\
\text { epididimitis semptomu gösterdi. Semen örneklerinin muayenesinde serolojik olarak pozitif ve negatif hayvanlar } \\
\text { arasında akrozomun hacmi, konsantrasyonu, kütle aktivitesi, motilitesi ve defektivite oranı açısından istatistiksel } \\
\text { olarak anlamlı bir fark bulunmadı. Serum örneklerinden } 20 \text { adedi anti-Brucella antikoru için negatif olmasına } \\
\text { rağmen, } 23 \text { adedi bruselloz için serolojik olarak pozitifti. Selektif besiyerinde yapılan katı ve sıvı kültürler ile } \\
\text { semen örneklerinden yapılan tür spesifik PCR testi sonucunda örneklerden Brucella saptanmadı. Bu durum, } \\
\text { numunelerin; hayvanların genellikle organizmaları saçmadığ1 kronik enfekte hayvanlardan toplanmış } \\
\text { olabileceğini göstermektedir. Periyodik örneklemenin brusellozun kesin tanısında ve insidensinin saptanmasında } \\
\text { yardımcı olabileceği düşünülmektedir. }\end{array}$ \\
\hline
\end{tabular}

(iD) http://orcid.org/0000-0003-4337-577X iD http://orcid.org/0000-0002-0377-2650 (iD http://orcid.org/0000-0002-2245-5781 iD $h t t p: / / o r c i d . o r g / 0000-0002-3593-6816$

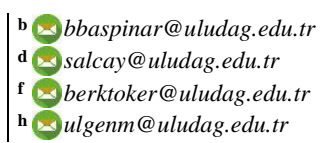

(iD) $h t t p: / / o r c i d . o r g / 0000-0001-5999-4685$ (iD) $h t t p: / / o r c i d . o r g / 0000-0002-2472-8157$ (iD) $h t t p: / / o r c i d . o r g / 0000-0003-4033-9749$ (iD) http://orcid.org/0000-0001-6101-6135 


\section{Introduction}

Brucellosis is manifested by reproductive failure, which includes abortion, the birth of unthrifty lamp and kids, and retained placentae in female animals. The disease is important for animals and humans because of the zoonotic potential of the disease. In Europe, animal brucellosis is still seen in Mediterranean and Balkan countries (Portugal, Spain, Italy, Malta, Bosnia-Herzegovina, Croatia, Greece, Cyprus, Turkey, Macedonia, and Serbia). Outside of this area, countries in Africa (Algeria), Asia (Syria, Iran) and Latin America (particularly Brazil and Mexico) are endemic countries for brucellosis in farm animals. Brucellosis is also a notifiable disease in Turkey, USA and Canada (Bauerfeind et al., 2016).

Brucella ovis causes clinical or subclinical disease of chronic evolution, characterized by testicular changes derived from the inflammatory process in the epididymis with seminal vesiculitis and ampulitis, followed by orchitis with subsequent loss of fertility in rams (Ridler and West, 2011, Carrera-Chávez, 2016). Lesions in Brucella-infected males are largely confined to the genital organs including testicles, seminal vesicles and epididymes (Morgan and MacKinnon, 1979). Brucellae are commonly present in the seminal fluid, accompanied by specific antibodies and may be transmitted to susceptible females through intra-uterine insemination (Crawford et al., 1990). It is noteworthy to mention that the artificial insemination is one of the main routes for infections of female animals. Although the semen from Brucella-infected bulls contains from 100 to 50,000 organisms $/ \mathrm{ml}$, infected bulls rarely transmit the disease through natural insemination (Morgan and MacKinnon, 1979; Adel et al., 2001).

For large scale diagnosis, the use of serological tests is recommended, plate agglutination tests with antigens prepared by smooth and rough strains, enzyme-linked immunosorbent assay and complement fixation tests, agar gel diffusion test are used mostly (Ridler and West, 2011). Infected rams may have intermittent excretion or no excretion of bacteria, which makes bacteriological analysis not practical or reliable. The clinical diagnosis by scrotal palpation is valid only if the animal has developed lesions and should be considered that epididymitis may be caused by other bacteria; moreover, infected rams without apparent clinical signs, may excrete the bacteria (Ficapal et al., 1998; Mejid et al., 2010, Carrera-Chávez et al., 2016). Rams/bucks and teaser animals should comply with the requirements before entring into an artificial insemination center and isolation at the pre-entry isolation facility where the country or zone of origin is not free from the diseases. OIE refers Brucellosis, Ovine epididymitis, Contagious agalactia, Peste des petits ruminants, Contagious caprine pleuropneumonia, Paratuberculosis, Scrapie, MaediVisna, Caprine arthritis/encephalitis, Bluetongue and Tuberculosis for ram and bucs (2019 C OIE - Terrestrial Animal Health Code - 10/08/2018).

Molecular testing of reproductive fluids (uterine/vagina discharge, semen) and urine from bovines is a useful tool for diagnosis of brucella but there is a little literature in this area for goat and sheep. Commercial ELISA kits are available for the diagnosis of Brucellosis. The routine diagnosis of brucellosis by detecting Brucella-DNA by PCR has been previously investigated (Fekete et al., 1990;
Adel et al., 2001). Although authors have evaluated the relationship between palpable lesions of epididymitis and semen quality in rams (Carvalho et al., 2012), according to the literature review, sperm quality in rams serologically positive to Brucella spp. naturally infected has been evaluated before by Carrera-Chávez et al. (2016). Therefore, this study aimed to evaluate sperm quality in naturally brucella-infected rams and goats which are also serologically positive for brucellosis and to isolate and identify Brucella spp. and the other bacteria in semen and tissues by bacteriological and molecular methods.

\section{Materials and Methods}

\section{Sample Processing}

This study was performed between the years 20122014 from a herd in Bursa which is located in Northwestern of Turkey. The herd included 206 goats and 38 sheep, totally 244 and had a history of brucellosis infection. For the detection of Brucella spp. and the other zoonotic bacterial agents, vaginal swabs and milk samples were taken from female goat (n:56) and ewe(n:5). Semen samples (n: 42) were collected from Saanen goats (n:34) and ram (n:8). The serum samples of sheep (n: 38) and goats (n:206) were also tested for Brucellosis by C-ELISA and I-ELISA. For this purpose, the team from Department of Artificial Insemination received separate ejaculation samples from, Saanen (n: 34), Ivesi (n: 3) and Kivircik (n: 5) for their spermatological examination.

\section{Clinical Examination and Semen Collection}

A total of 43 semen samples from adult rams (n:8) and goats(n:35) were collected for semen examinations. Animals were 3 to 4 years old and were, maintained in a breeder herd in Turkey. Each animal was examined by genital palpation to detect macroscopic testicular alterations. Clinical examination was performed by manual palpation of both testicles and epididymis simultaneously. Comparing to each other, symmetry, size, shape and consistency of both testicles were assessed and recorded. The epididymides were palpated, starting from the head, continuing to the body and the tail. Semen was collected by electrostimulation with an electroejaculator standardized for small ruminants, produced by MINITUBE-Germany (Ustuner et al., 2016). To collect semen, ram and goats were restrained physically and lubricated probe was inserted into the rectum with downward pressure on the front of the probe so the electrodes remained nearby the upper portion of the ampullary region. The electrical stimulation was applied for 4-8 s. While the electro stimulation was stopped briefly (3-4s), further massage was applied with the probe. This cycle was repeated until 1.0-2 ml semen was collected (usually 3-4 electro stimulations). Collected semen was placed in a warm water bath $\left(30^{\circ} \mathrm{C}\right)$. Macroscopic analysis of semen characteristics, including volume, color, and viscosity was done clinically. Then, semen was evaluated immediately for consistency, wave motion (0-5 scale), percentage of motile spermatozoa (\%) and defected acrosome rate (\%) (Ustuner et al., 2016). 


\section{Semen Evaluation}

All semen parameters were assessed by the same person on each occasion throughout the study. Sperm counts were performed with the hemocytometer method. Sperm motility was assessed subjectively using a phasecontrast microscope (Olympus BX 51) (400x) with a warm slide $\left(38^{\circ} \mathrm{C}\right)$. Acrosomal and other morphological integrity were evaluated by Giemsa staining technique (Ustuner et al., 2016).

\section{Culture}

Each of semen samples (n:43) were investigated for the diagnosis of Mycoplasma spp., Ureaplasma spp., E.coli, Klebsiella spp, Acinetobacter spp., Trueperella pyogenes, Brucella melitensis, B.ovis, Listeria monocytogenes, and Campylobacter spp. by routine bacteriological procedures. For this purpose, a loop of all freshly collected semen samples were inoculated on to Columbia agar (COS43041; bioMérieux) with 7 percent defibrinated sheep blood, MacConkey's agar (CM115; Oxoid) and Levine eosin methylene blue agar (CM0069B; Oxoid), XLT-4 Agar Base (BD, Difco®- 223420) supplemented with XLT-4 Supplement (BD Difco ${ }^{\text {TM}}-100 \mathrm{~m}$ ) for the detection of aerobic bacteria. The plates were incubated for 24 hours at $37^{\circ} \mathrm{C}$. Listeria Selective Agar (Oxoid®-CM0856B) containing Listeria Selective Supplement Oxoid $囚-S R 0141 E)$ were used for the detection of Listeria species from semen samples. Semen samples were diluted in Mycoplasma Broth Base (CM0403; Oxoid) containing Mycoplasma Supplement G (SR0059C; Oxoid) to $10^{-3}$ and inoculated to Mycoplasma Agar Base (CM0401B; Oxoid) plates containing Mycoplasma Supplement G (SR0059C; Oxoid) for isolation of Mycoplasma spp. All samples were also streaked onto Brucella Selective Medium Base Oxoid®-CM0169 containing Brucella Selective Supplement (Oxoid® SR0083) and Butzler SelectiveMedium (Colombia Blood Agar Base) (Oxoid®-CM0331B) containing Butzler- Campylobacter Selective Supplement (Oxoid $\AA$ - SR-0085E) for the isolation of Mycoplasma, Brucella and Camphylobacter species, respectively. All plates were incubated for seven days at $37^{\circ} \mathrm{C}$ in a humidified atmosphere with $5-10 \% \mathrm{CO}_{2}$. Mycoplasma broth media and agar plates were examined daily for signs of mycoplasma growth. Mycoplasma-like colonies and typical 'fried egg' colonies were examined under 35X magnification of stereomicroscope. Mycoplasma-like growth was tested to digitonin sensitivity for Acholeplasmas and urease activity for Ureaplasmas using standard methods (Poveda et al., 1998).

Since semen samples may contain relatively few brucellae, Brucella spp. detection procedure was based on two-stage culturing i.e., selective enrichment in liquid culture medium and inoculation on to three different selective solid media, namely Farrel's, modified ThayerMartin and Cita. For selective enrichment tryptic soy broth (BBL) containing 5-10\% fatal calf serum amphotericin B (1 $\mathrm{mg} / \mathrm{ml}$ ), and vancomycin $(20 \mathrm{mg} / \mathrm{ml})$ was used. Semen samples $(0.1 \mathrm{ml})$ were inoculated into each of this broth and incubated at $37^{\circ} \mathrm{C}$ in air supplemented with $5-10 \% \mathrm{CO}_{2}$, for six weeks, with weekly passages on to solid selective media. Farrel's medium was prepared by adding 5-10\% serum and antibiotic supplement into the basic medium (Oxoid SR0083A). Modified Thayer-Martin's (GC Medium Base, $38 \mathrm{~g} /$ litter; BIOLIFE Laboratories, Milan, Italy) was prepared by adding hemoglobin (10 g/litter, Difco), colistin methanesulphonate $(7.5 \mathrm{mg} / \mathrm{litter})$, vancomycin (3 $\mathrm{mg} /$ litter), nitrofurantoin (10 mg/litter), nystatin $(100,000$ International Units [IU]/litter $=17.7 \mathrm{mg}$ ) and amphotericin B (2.5 mg/litter) (Sigma) to the basic media. Cita medium included basic medium, 5-10\% fatal calf serum, colistin methanesulphonate $(7.5 \mathrm{mg} / \mathrm{litter})$, by adding vancomycin (20 mg/litter), nitrofurantoin (10 mg/litter), nystatin $(100,000$ International Units [IU]/litter $=17.7 \mathrm{mg})$ and amphotericin B (4 mg/litter) (Sigma)

\section{Competitive ELISA (C-ELISA)}

Svanovir ${ }^{\circledR}$ (Svanova) Brucella diagnostic C-ELISA kit was used according to the manufacturer instructions. for screening Brucella lipopolysaccharide (LPS) antigen of smooth Brucella strains. Positive, negative, weak positive and conjugate controls (20 $\mu$ l of sample dilution buffer) and serum samples were prediluted $1 / 10$ in tubes by adding $20 \mu 1$ of respective control or sample into $180 \mu 1$ of Sample Dilution Buffer. Prediluted controls and samples in the volume of $50 \mu \mathrm{l}$ were placed into appropriate wells, respectively Mouse monoclonal antibody (mAb) specific of an epitope on the O-polysaccharide of S-LPS antigen of Brucella abortus, of were added $50 \mu 1$ in each well. The plates were incubated with the test serum and mAbs by shaking for 5 minutes and then $30 \mathrm{~min}$. without shaking in room temperature. All plates were rinsed four times and then $100 \mu \mathrm{l}$ of Substrate Solution containing goat antimouse IgG antibody conjugated with horse-radish peroxidase was added into wells and the plates were incubated $30 \mathrm{~min}$ for a binding reaction.

\section{Indirect ELISA (I-ELISA)}

Chekit ${ }^{\circledR}$ (Idexx) Brucellosis serum antibody Test kit was used according to the manufacturer instructions for Indirect- ELISA. The volume of $90 \mu \mathrm{l}$ of washing solution was plated each well and $10 \mu \mathrm{l}$ of undiluted serum sample and controls were added into appropriate wells comprising up to final dilution at 1:10. After the incubation for $60 \mathrm{~min}$ at $37^{\circ} \mathrm{C}$, all wells were dispended with $300 \mu \mathrm{l}$ of washing solution three times. Check it -Brucellosis Anti Ruminant Ig-PO conjugate was added then and the plate was incubated for 60 minutes at $37^{\circ} \mathrm{C}$.

\section{$P C R$}

A target sequence of a gene encoding $31 \mathrm{kDa}$ protein (BCSP31) which is common in all Brucella spp. was amplified by PCR. F B4 (5 'CTC GGT TGC TGG TAT CAA CAA 3') and B5, R (5 'CGC GCT GGT TCA CTT CTG TGC 3') (Sigma-Aldrich) were used as primers. Amplification protocol was performed described by Baily et al. with minor modifications (1992). Bacterial DNA was obtained by boiling method from culture medium containing semen samples. The reaction volume was $50 \mathrm{ul}$ including $10 \mathrm{mMTris}-\mathrm{HCl}$ (pH8.4), $50 \mathrm{mMKCl}, 1 \mathrm{mM}$ magnesium chloride, $200 \mathrm{mMdNTP}$ (Fermentas), $1.25 \mathrm{U}$ of Taq polymerase (Roche). Five microliters of the PCR amplicon were loaded into a $1.5 \%$ (wt/vol) agarose gel (SeaKem -Lonza) in 1X TAE buffer using EzVision One loading dye (Amresco) and run concurrently. DNA Ladder (100 bp) (SM0241, $50 \mu \mathrm{g}$ Thermo Scientific) and the PCR products obtained from the positive and negative control were included in each run. No bands at 223 bp were visualized in an UV-Tech Fire Reader (Progen Scientific, Merton, London, SW19 3UU). 
Statistical Analysis

All data were analysed using the SPSS statistical package (SPSS 23.0 for Windows; SPSS, Chicago, IL, USA). Means of obtained semen parameters were analysed using the Mann Whitney $U$ test. Data were considered statistically significant when $\mathrm{P} \leq 0.05$.

\section{Results and Discussion}

\section{Clinical and Semen Laboratory Examinations}

There were no symptoms in rams at clinical examination, however, two serologically positive rams showed orchitis and one ram showed epididymitis, which was negative serologically for brucellosis. The volume and concentration of semen, mass activity, percentages of motility and defective acrosome rates in serologically positive and negative small ruminants are presented in Table 1 .

There were no significant differences between serologically positive and negative animals for volume, concentration, mass activity, motility and defective acrosome rates $(\mathrm{P}>0.05)$. Although there were no differences in spermatological parameters between serologically positive and negative animals, motility rate was $20 \%$ less in two animals with orchitis and serologically positive.

\section{Bacteriological Results}

As a result of bacteriological culture Trueperella pyogenes (n:2), Pasteurella pneumotopica (n: 5), Esherichia coli (n: 3), Aeromonas salmonicida subs. Salmonicida (1), Brevundimonas vesicularis (n:2), Mycoplasma bovigenitalium (n:1) and Mycoplasma arginini (n:1) were isolated from semen samples of ram and goats. Listeria spp., Campylobacter spp., Corynebacter spp., Aeromonas spp., Staphylococcus spp., Streptococcus spp., Klebsiella spp. Ureaplasma spp. and Salmonella sp. were not isolated from any of the specimens. Brucella spp. were not isolated from the semen samples.

\section{Molecular Results}

No specific band for genus-specific PCR was observed in PCR.

\section{Serological results}

Competitive ELISA and Indirect ELISA results were positive for 8 serum samples taken from ram and goats. Weak positivity was seen in 17 samples and 18 were negative for both C-ELISA and I-ELISA. The results were shown in Table 2.

\section{Discussion}

In this study, semen samples which were collected from the serologically positive herd were subjected to examination for spermatologic characteristics and diagnosis by culture method, and PCR assay for the detection of Brucella spp. DNA. Brucellae did not grow culturally from the semen of rams and goats. Even serologically positive animals and weak positives were negative for Brucellae by culture method and PCR. That may be attributed to the sampling time. Samples collected at chronic stages of infection might contain few organisms or not at all. It was previously reported that during the chronic stages of the disease when the foci of infection become walled off, infected animals stop excreting the organism (Morgan and MacKinnon, 1979). On the other hand, Corbel (1985), declared that some animals may show false seropositive results due to infection by other Gram-negative microorganisms. Brucella spp. were not isolated from the semen samples either directly plated from the solid selective medium or, liquid cultures weekly sub cultured. The negative or false-negative bacteriological results may also be attributed to massive contamination of semen samples and antibiotics given to animals by the owner, (Blasco, 1992). Alton et al. (1988) and Adel et al (2001) declared that a wide variety of culture methods used in different laboratories resulted in considerable differences in performance, variable success and some degree of difficulty. Khamesipour et al. (2013) randomly collected 84 bull's and ram's testis, 45 cattle semen and 315 cattle and sheep blood specimens from slaughterhouses and Artificial Insemination Centre in various parts of Iran. PCR detection for Brucella was directly studied from blood, semen and testis samples. PCR results showed that 14 out of 45 cattle semen samples (31.11\%), and 63 out of 180 cattle blood samples (35\%), and 42 out of 135 sheep's blood samples (31.11\%), were positive for Brucella spp. Their study indicated that the testis samples in $15.21 \%$ of bulls and the testis samples in $10.52 \%$ of rams served as a reservoir of disease in Iran and these samples might have been a potential risk for spread of Brucella both in animal and in human. In our study, the testicular tissues were not used as a sample, only semen samples were taken from each ram separately. Despite specimens and serum samples were serologically titrated after vaccination or infections; Brucella infection was not spread out through the semen in this study.

Brucella spp. detection procedure was implemented by using Farrel's, modified Thayer-Martin and Cita selective solid media. Brucella ovis was not detected in any of semen samples neither by culture nor by PCR. Therefore, it is essential that the diagnosis of $B$. ovis be carried out by serological diagnosis, and be part of the evaluation of fertility in rams, since other bacteria can cause epididymitis or there may be infected animals without apparent clinical signs and relative difficulty in isolating causative agent in chronically infected animals (Ficapal et al., 1998; Mejid et al., 2010). Chronically infected animals and latent carriers may have subfertility or maintain normal fertility, increasing the risk of infection in the flock (Xavier et al., 2009). The culture results of the semen samples in this study showed a variety of the organisms excreted by semen such as; Trueperella pyogenes (n:2), Pasteurella pneumotopica (n:5), Esherichia coli (n:3), Aeromonas salmonicida subs. Salmonicida (1), Brevundimonas vesicularis (n:2) and Mycoplasma vesicularis (n:2), Mycoplasma bovigenitalium (n:1) and Mycoplasma arginini (n:1). Low sperm motility $(60 \%)$ and the semen contamination by Mycoplasmas and Urea plasmas were observed in reproductive animals (Eaglesome et al., 1992; Fish et al., 1985, Catania et al., 2014). Mycoplasma bovigenitalium, previously called Mycoplasma ovine/caprine serogroup 11 (Corrales et al., 2007; Nicholas et al., 2002), was originally isolated from infertile ewes having been introduced by infertile rams that showed abnormal sperm morphology and motility (Lambert, 1987). It has been associated with vulvovaginitis, epididymitis, orchitis, and infertility, resulting in economic losses. Mycoplasma bovigenitalium was introduced by infertile rams showing abnormal sperm morphology and motility (Nicholas et al.,1999). 
Table 1 The effect of Brucella spp. on sperm parameters (means \pm SEM).

\begin{tabular}{c|cccccc}
\hline Group & $\mathrm{n}$ & $\begin{array}{c}\text { Volume } \\
(\mathrm{ml})\end{array}$ & $\begin{array}{c}\text { Mass Activity } \\
(+,+++)\end{array}$ & $\begin{array}{c}\text { Motility } \\
(\%)\end{array}$ & $\begin{array}{c}\text { Concentration } \\
(\mathrm{x} 109 \text { spermatozoa/mL) }\end{array}$ & $\begin{array}{c}\text { Defective Acrosome } \\
(\%)\end{array}$ \\
\hline Brucella $(-)$ & 17 & $2.07 \pm 0.28$ & $2.71 \pm 0.28$ & $58.24 \pm 4.39$ & $2.91 \pm 0.32$ & $15.19 \pm 1.68$ \\
Brucella $(+)$ & 25 & $1.75 \pm 0.24$ & $\underline{2.76 \pm 0.21}$ & $55.00 \pm 4.08$ & $2.40 \pm 0.22$ & $19.25 \pm 3.95$ \\
\hline
\end{tabular}

There was no significant difference $(\mathrm{P}>0.05)$.

Table 2 Semen culture and ELISA results of ram and goats used in this study

\begin{tabular}{|c|c|c|c|c|c|}
\hline List & Animal & Breed & C-ELISA & I-ELISA & Semen Culture \\
\hline 1 & Goat & Saanen & $+?$ & $?$ & \\
\hline 2 & Goat & Saanen & $?$ & _ & Brevundimonas vesicularis \\
\hline 3 & Goat & Saanen & - & & Aeromonas salmonicida subs. Salmonicida \\
\hline 4 & Goat & Saanen & - & - & \\
\hline 5 & Goat & Saanen & - & - & Mycoplasma arginini, Trueperella pyogenes \\
\hline 6 & Goat & Saanen & - & - & \\
\hline 7 & Goat & Saanen & $?$ & - & \\
\hline 8 & Goat & Saanen & $?$ & ? & \\
\hline 9 & Goat & Saanen & $+?$ & $?$ & E.coli 1 \\
\hline 10 & Goat & Saanen & $?$ & - & Mycoplasma agalactiae \\
\hline 11 & Goat & Saanen & $?$ & - & \\
\hline 12 & Goat & Saanen & - & - & Brevundimonas vesicularis \\
\hline 13 & Goat & Saanen & - & $?$ & \\
\hline 14 & Ram & İvesi & $?$ & - & Mycoplasma agalactiae \\
\hline 15 & Goat & Saanen & $?$ & $?$ & Mycoplasma agalactiae \\
\hline 16 & Goat & Saanen & $?$ & - & \\
\hline 17 & Goat & Saanen & & & \\
\hline 18 & Goat & Saanen & - & - & E.coli 1, Pasteurella spp. \\
\hline 19 & Goat & Saanen & + & + & \\
\hline 20 & Goat & Saanen & & $?$ & \\
\hline 21 & Goat & Saanen & $+?$ & - & \\
\hline 22 & Goat & Saanen & $?$ & $?$ & \\
\hline 23 & Goat & Saanen & _ & - & \\
\hline 24 & Goat & Saanen & & - & \\
\hline 25 & Goat & Saanen & + & + & Pasteurella pneumotropica \\
\hline 26 & Goat & Saanen & $?$ & $?$ & \\
\hline 27 & Goat & Saanen & $?$ & - & \\
\hline 28 & Goat & Saanen & $+?$ & - & Mycoplasma bovigenitalium \\
\hline 29 & Goat & Saanen & + & $?$ & \\
\hline 30 & Goat & Saanen & _- & _ & \\
\hline 31 & Goat & Saanen & - & - & \\
\hline 32 & Goat & Saanen & - & - & \\
\hline 33 & Goat & Saanen & ? & - & Pasteurella pneumotropica \\
\hline 34 & Ram & Kivircik & $+?$ & & \\
\hline 35 & Ram & İvesi & $?$ & $?$ & \\
\hline 36 & Ram & İvesi & _- & $?$ & \\
\hline 37 & Ram & Kivircik & - & - & \\
\hline 38 & Ram & Kivircik & - & - & Trueperella pyogenes, E.coli \\
\hline 39 & Goat & Seannen & - & - & \\
\hline 40 & Goat & Seannen & - & - & \\
\hline 41 & Ram & Kivircik & & & E.coli 1 \\
\hline 42 & Ram & Kivircik & & & Pasteurella pneumotropica \\
\hline 43 & Goat & Saanen & $?$ & _ & \\
\hline
\end{tabular}

Brevundimonas is one of few bacteria showing high survival rates under simulated Martian conditions (Dartnell et al., 2010). The Brevundimonas species are ubiquitous in the environment but are rarely isolated from clinical samples. In this study, two of Seannen goats carried Brevundimonas vesicularis without any symptoms, also they were serologically negative for Brucella. In this study, Aeromonas salmonicida subs. salmonicida was also identified from a goats' ejaculate for the first time. In a study, Aeromonas hydrophila was isolated from cases of bovine seminal vesiculitis in south Brazil (Moro et al., 1999). Seminal vesiculitis in teaser animals associated with Actinomyces pyogenes, Escherichia coli, Brucella abortus, Mycoplasma bovigenitalium, Haemophilus somnus, and Pseudomonas aeruginosa have been described before (Ball et al., 1968, Quinn et al., 2003) Bacterial organisms can migrate up the urethra of teaser animals to the internal reproductive organs and urethra (ascending infection) is a 
possible route of an infection. Also, the homosexual activity of young goats and rams confined together is high, and if there were an infectious agent within a group of bucks, adequate opportunity for preputial and penile contamination could exist (Ball et al., 1968; Moro et al., 1999). A theory concerning the pathogenesis of seminal vesiculitis syndrome associated with the neurophysiologic events that could result in reflux of spermatozoa and urine into vesicular glands in teaser animals. Semen or urine could cause chemical irritation and loss of glandular integrity, resulting in further colonization by microorganisms (Linhart et al., 1988).

In this study, the serological results by Competitive ELISA and Indirect ELISA showed positivity for twentyfive [n:25 (59.52\%)] serum samples. Seventeen [n:17 $(40.48 \%)]$ were negative for both C-ELISA and I-ELISA, which are the serological tests employed in this study are proved to be highly sensitive according to Alton et al., (1988). However, in our study, we used serological tests that only detect smooth lipopolysaccharide which is absent in B.ovis. Therefore, in our study, all serologically positive animals were assumed to be exposed to smooth Brucellae. On the other hand, it has been reported that male sheep and goats in an infected herd were not infrequently become infected with B.melitensis themselves. In our study, orchitis was diagnosed in two bucks in the serologically positive group. These findings agree with Andreani et al. (1967), who observed that rams were positive serologically, yet none developed any symptoms, and all were negative pathologically and bacteriologically when sacrificed 7 or 8 months after exposure to infection source. Additionally, seven (n:7) out of twenty-six (n:26) B. ovis strains $(26.9 \%)$ were cultured from the epididymites of rams which did not show palpable epididymal and/or testicular lesions (Dénes and Glávits, 1994). The reason for the absence of testicular inflammation in all serologically positive cases may be associated with the chronicity of the infection. In a study done by Van Metre et al. (2012) indicated that $53.6 \%$ of seropositive rams to $B$. ovis had a normal fertility evaluation, without abnormalities detected on physical examination or semen. In this study, similar results were observed in terms of semen volume, concentration, mass activity, motility and defective acrosome rates in serologically positive and negative groups $(\mathrm{P}>0.05)$. However, sperm motility and other spermatologic characteristics were negatively affected by testicular or epididymal lesions regardless of serological reactions to smooth Brucella spp.

Generally, in Brucella infections, epididymal ducts show epithelial hyperplasia with interepithelial cysts containing neutrophils and cellular debris. Testicular atrophy derives regressive process in the testicular epithelium and cessation of spermatogenesis. Infected rams show poor semen quality and lowered fertility. Both the total concentration and the proportion of normal living spermatozoa are spectacularly reduced in rams with testicular alterations Even in the absence of palpable epididymitis, infected animals may have poor semen quality. (Blasco, 1990; Cameron and Lourman, 1976). In the present study, the infection with Brucella spp. occurred naturally; considering this, the percentage of animals serologically positive that presented testicular lesion was lower $(4.76 \%)$ than $(30.56 \%)$ decelerated by CarreraChávez et al. (2016).
In this study, the distribution of Brucella-DNA in semen was determined by separating naturally infected semen samples into seminal plasma which were then analysed by the PCR assay. All semen samples derived from different rams and goats were fractionated. The template DNA from each seminal fraction derived from equivalent amount of semen was analysed by PCR using specific primers for Brucella genus detection (Bricker and Halling, 1994). None of the amplicons yielded $223 \mathrm{bp}$ fragment in PCR. A protocol was adopted to purify Brucella-DNA from bovine and ovine semen samples by Von Beroldingen et al. (1990) who concluded that direct PCR detection of $B$. melitensis DNA in semen was impractical due to the presence of inhibitory components in semen (Von Beroldingen et al., 1990). Preliminary experiments regarding the isolation methods suggested that most Brucellae might be present in the non-sperm cell fraction. This finding may be supported by the conclusions previously reported by Adel et al. (2001). The inhibition might have been observed in whole semen samples was primarily due to the high DNA concentrations. A similar finding was previously reported by Von Beroldingen et al. (1990) and Adel et al. (2001). It is important to prevent transmission of brucellosis by artificial insemination, only Brucella-free semen collected from Brucella free donors should be used (Adel et al., 2001). The first PCR assay for detection of Brucellae in semen samples of goats and rams was reported by Adel et al. (2001). They concluded that the PCR assay was a good supplementary test for detection of Brucella organisms in the semen of infected animals. They also recommended the use of the PCR, as a routine assay, for the detection of Brucella-DNA in seminal fluid and non-sperm cell fractions rather than on whole semen samples. They recommended the PCR assay could be of value in examining semen samples obtained from donor animals of the unknown history of the disease or suspicious animals; showing week serological results. Considering the data of our work, although serological tests were defined as weak positive or positive for smooth Brucellae, they were all negative in culture and PCR from semen samples. This contradiction suggests that the scattering of Brucella with semen may be intermittent depending on the pathogenesis of the disease. In sheep and goat males, the infection can be located in testis, epididymis, seminal vesicle and ampulla of deferent ducts, producing inflammation of genital organs. In the acute phase, it can be detected orchitis with inflammation of tunica vaginalis, and the scrotal sac can be distended by either hemorrhagic or fibrino-purulent exudate. In a chronic stage, hygromas and joints' inflammation can be observed in male goats. The main output of the disease in males is semen of bad quality and a consequent fertility loss (Megid et al., 2010; Enright, 1993; Leon, 1994; Jubb, 1993). This study commentated that Brucella might not be detected via spread out through the sperms, which may be attributed to the stage of sampling or few organisms in semen that might not allow isolation of the organism. Asymptomatic carriage of Brucella spp. in rams and goats should be detected in herds and artificial insemination centres every 6 months. The surveillance protocols should be applied to reduce the risk of transmission of Brucella infection to prevent the rams and goats. To achieve these goals, serological tests that also detect rough Brucella species 
including B.ovis need to be developed and used routinely as a part of the serologic diagnosis of brucellosis in general for a more accurate evaluation of the disease in sheep and goats.

\section{Acknowledgements}

The study was approved by the Ministry of Food, Agriculture and Livestock General Directorate of Food and Control on 05.23.2018 under the title of 'Investigation of the stemmatological characteristics and bacteriological load of the goats' and rams' sperms at Bursa and surroundings. The title of the article was then changed during the preparation phase of the manuscript.

\section{References}

Alton GG, Jones LM, Angus RD, Verger JM. 1988. Bacteriological methods. In: Techniques for the Brucellosis Laboratory. INRA. pp 13-61. Conference Animal Diseases 2009, Royal Holloway, University of London UK, 2-4 September.

Alton Godfrey G. 1990. Edited by Nielsen Klauss, Duncan J. Robert, Animal Brucellosis, Chapter 16 Brucella melitensis, 1887 to 1997, Chapter 17 Brucella melitensis, pp:379--411), CRC Press, Boca Raton, USA, 1990.

Andreani E. 1967.Decorso dell'infezione brucellare in montoni sotoposti a contagio naturale. Ann Fac Med Vet Pisa, 19, 331

Adel S, Amina AS, Mahmoud ER, Hamdyb, Adel KI. 2001. Detection of Brucella melitensis in semen using the polymerase chain reaction assay. Veterinary Microbiology. 83(1): 37-44 https://doi.org/10.1016/S0378-1135(01)00401-1

Baily GG, Krahn JB, Drasar BS, Stoker NG. 1992. Detection of Brucella melitensis and Brucella abortus by DNA amplification. Journal of Tropical Medice and Hygien 95:271-275.

Ball L, Young S, Carroll EJ. 1968, Seminal vesiculitis syndrome: lesion in genital organs of young bulls. Am J Vet Res 29:1173-1184.

Bauerfeind R, von Graevenitz A, Schiefer AKHG, Slenczka TSW, Zahner H. 2016. Zoonoses Infectious Diseases Transmissible Between Animals and Humans, Pp:191-195, 2 Bacterial Zoonoses, 2.5 Brucellosis. ISBN 978-1-55581-9255 e-ISBN 978-1-55581-926-2 doi:10.1128/9781555819262, ASM Press, 1752 N St., N.W., Washington, DC 20036-2904, USA

Blasco JM, 1990. Chapter 15 Brucella ovis, Edited by Nielsen Klauss, Duncan J. Robert, Animal Brucellosis, pp:351-378

Blasco JM. 1992. Diagnosis of Brucella melitensis infection in small ruminants. In: Plommet, M. (Ed.), 247 Prevention of Brucellosis in the Mediterranean Countries. Pudoc Scientific Publishers, Wageningen, The 248 Netherlands, pp. 272-278.

Bricker BJ, Hallıng SM. Journal of Clinical Microbiology, Nov. 1994, American Society for Microbiology. Differentiation of Brucella abortus bv. 1, 2, and 4, Brucella melitensis, Brucella ovis, and Brucella suis bv. 1 by PCR. 32(11): 2660-2666.

Cameron RD, Lauerman LH. 1976.Characteristics of semen changes during Brucella ovis infection in Rams., Veterinary Record. 99(12): 231-233, DOI: 10.1136/vr.99.12.231

Carvalho Júniora CA, Moustacasa VS, Xaviera MN, Costaa EA, Costaa LF, Silvaa TMA, Paixãob TA, Borgesa AM, Gouveiac AMG, Santos RL. 2012. Andrological, pathologic, morphometric, and ultrasonographic findings in rams experimentally infected with Brucella ovis. Small Ruminant Research Volume 102, Issues 2-3, February 2012, Pages 213222 https://doi.org/10.1016/j.smallrumres.2011.08.004.
Corbel MJ. 1985.Recent advances in the study of Brucella antigens and their cross reactions. The Veterinary bulletin 55: 927-94

Catania S, Tavella A, Gobbo F, Ashley R, Nicholas J. 2014. The isolation of Mycoplasm bovigenitalium from infertile dairy cattle.Veterinary Record Case Reports, 2(1): 1-2

Carrera-Chávez JM, Quezada-Casasola A, Pérez-Eguia E, ItzáOrtíz MF, Gutiérrez-Hernández JL. 2016. Sperm quality in naturally infected rams with Brucella ovis, Small Ruminant Research. 144: 220-224. https://doi.org/10.1016 /j.smallrumres.2016.09.021

Crawford RP, Huber JD, Adams BS, Chapter 7 Epidemiology and Surveillence, Edited by Edited by Nielsen Klauss, Duncan J. Robert, Animal Brucellosis, pp:131- 152, CRC Press, Boca Raton, USA, 1990.

Corrales JC, Esnal A, Sánchez A, Assunçao P, Poveda JB, Contreras A. 2007. Contagious agalactia in small ruminants. Small Ruminant Research, 68 (1-2): 154-166. https://doi.org/10.1016/j.smallrumres.2006.09.010

Dartnell LR, Hunter SJ, Lovell KV, Coates AJ, Ward JM. 2010. "Low-Temperature Ionizing Radiation Resistance of Deinococcus radiodurans and Antarctic Dry Valley Bacteria”. Astrobiology, 10(7): 717-32. Bibcode: 2010AsBio10.717D.doi:10.1089/ast.2009.0439.PMID20950 171.

Dénes B, Glávits R. 1994. Bacteriologically confirmed cases of ovine epididymo-orchitis caused by Brucella ovis in SubCarpathia. Acta Vet Hungaria.;42(1): 25-33.

Eaglesome MD, Garcia MM, Stewart RB. 1992. Microbial agents associated with bovine genital tract infections and semen. Part II. Haemophilus somnus, Mycoplasma spp and Ureaplasma spp, Chlamydia; pathogens and semen contaminants; treatments of bull semen with antimicrobial agents. The Veterinary Bulletin, 62: 887-910

Enright FM. 1990. The pathogenesis and pathobiology of infection in domestic animals. Animal brucellosis.In: Nielsen \& Duncan, Eds. CRC Press, Boca Ratón: Florida, USA, 301320.

Fekete A, Bantle JA, Halling SM, Sanborn MR. 1990. Preliminary development of a diagnostic test for Brucella using polymerase chain reaction. Journal of Applied Bacteriology, 69(2): 216-27.

Ficapal A, Jordana J, Blasc JM, Moriyón I. 1998. Diagnosis and epidemiology of Brucella ovis infections in rams. Small Rumin. Res. 29: 13-19

Fish NA, Rosendal S, Miller RB. 1985. The distribution of Mycoplasmas and Ureaplasmas in the genital tract of normal artificial insemination bulls. The Canadian Veterinary Journal, v.26, pp.13-15

Gouletsou G, Fthenakis GC. 2015. Microbial diseases of the genital system of rams or bucks P. Vet Microbiol, Dec 14;181(1-2):130-5. doi: 10.1016/j.vetmic.2015.07.016. Epub 2015 Jul 15.

Hamdy MER, Amın AS. 2002. Detection of Brucella Species in the Milk of Infected Cattle, Sheep, Goats and Camels by PCR The Veterinary Journal, 163: 299-305 doi:10.1053 /tvjl.2001.0681

Jubb KVF, Kennedy PC, Palmer N. 1993. Pathology of domestic animals. 4th ed. Academic Press: San Diego, California, USA, 3: 653 .

Kaushik P, Singh DK, Tiwaril AK, Kataria RS. 2006. Rapid Detection of Brucella Species in Cattle Semen by PCR. J. Appl. Anim. Res. 30: 25-28.

Khamesipour F, Doosti A, Taheri H. 2013. Molecular Detection of Brucella Spp. İn The Semen, Testis and Blood Samples of Cattle And Sheep, Journal of Pure and Applied Microbiology, 7(Spl. Edn.): 495- 
Lambert M. 1987. Contagious agalactia of sheep and goats. Rev Sci Tech Off Int Epiz,. 6(3): 699-711.

Nicholas RAJ, Wessels M, Orme PK, Wood E, Sachse K. 1999. Isolation of Mycoplasma ovine/caprine serogroup 11 from infertile sheep in Britain. Veterinary Record 145: 434-435

Leon CF. 1994. Brucelosis ovina y caprina, Ed. Office International dês Epizooties - OIE. Paris: Franci: 451.

Inhart RD, Parker WG. 1988, Seminal vesiculitis in bulls. Compend Cont Ed Pract Vet 10: 1429-1448.

Mejid J, Mathias LA, Robles CA. 2010. Clinical manifestations of brucelosis endomestic animals and humans. Open Vet. Sci. 4: 119-126.

Morgan WJB, MacKinnon DJ, 1979. Brucellosis, In laining, JA,Fertility and infertility in domestic animals, 3rd edition, ELBS, Bailliere Tindall, Chapter 9: 171-198.

Moro BEMP, Weiss RDN, Friedrich RSC, Vargas AC, Weiss LHN, Nunes MP. 1999. Aeromonas hydrophila isolated from cases ofbovine seminal vesiculitis in South Journal of Veterinary Diagnostic Investigation 11: 189-191.

Nicholas RA, Khan LA, Houshaymi B, Miles RJ, Ayling RD, Hotzel H, Sachse K. 2002. Close genetic and phenotypic relatedness between Mycoplasma ovine/caprine serogroup 11 and Mycoplasma bovigenitalium. Systematic and Applied Microbiology, 25(3): 396-402.

OIE. 2009. Office International dês Epizooties, Manual of Standards for Diagnostic tests and Vaccines. Third edition. Office International of Epizooties, Paris, France. Caprine and ovine brucellosis. Chapter (2.7.2), Bovine Brucellosis chapter (2.4.3).

Poveda J. 1998. Biochemical Characteristics in Mycoplasma Identification. In: Miles, R, Nicholas, R. (Org.). Mycoplasma Protocols. New Jersey, Totowa: Humana Press Inc, V. 104: 37-50: 69-78.
Prats-van der Ham M, Tatay-Dualde J, Fe C, Paterna A, Sánchez A, Corrales JC, Contreras A. Gómez-Martín A. 2017. Detecting asymptomatic rams infected with Mycoplasma agalactiae in ovine artificial insemination centers, Theriogenology 89: 324-328.

Ridler AL, West DM. 2011. Control of Brucella ovis Infection in Sheep, Vet Clin Food Anim 27 61-66 doi:10.1016 /j.cvfa.2010.10.013

Quinn PJ, Markey BK, Carter ME, Donnely WJ, Leonard FC, 2003. Chapter 78, Interactions of microbial pathogens with the male and female reproductive systems, pp:450-456, in Veterinary Microbiology and Microbial Diseases. Blackwell publishing, ISBN:0-632-05525.

Ustuner B, Alcay S, Toker MB, Nur Z, Gokce E, Sonat FA, Gul Z, Duman M, Ceniz C, Uslu A, Sagirkaya H, Soylu MK. 2016. Effect of rainbow trout (Oncorhynchus mykiss) seminal plasma on the post-thaw quality of ram semen cryopreserved in a soybean lecithin-based or egg yolk-based extender. Anim Reprod Sci 164: 97-104.

Van Metre DC, Rao S, Kimberling CV, Morley PS. 2012. Factors associated with failure in breeding soundness examination of Western USA rams. Prev. Vet. Med. 105: 118-126.

Von Beroldingen CH, Blake ET, Higuchi R, Sensabaugh GF, Erlich HA. 1990. Application of PCR to 284 the analysis of biological evidence. In: Erlich, H.A. (Ed.), 1, PCR Technology: Principles and Applications 285 for DNA Amplification. Stockton Press, New York, pp. 209-223.

Xavier MN, Azebedo CE, Alves PT, Lima SR. 2009. The genus Brucella and clinical manifestations of brucelosis. Ciência Rural 39: 2252-2260. 